\title{
The role of rumen-protected choline in hepatic function and performance of transition dairy cows
}

\author{
Arash Shahsavari ${ }^{1}$, Michael J. D'Occhio ${ }^{2}$ and Rafat Al Jassim ${ }^{1 *}$ \\ ${ }^{1}$ School of Agriculture and Food Sciences, University of Queensland, Gatton campus, Gatton, QLD 4343, Australia \\ ${ }^{2}$ School of Life and Environmental Sciences, Centre for Carbon, Water and Food, Faculty of Agriculture and Environment, \\ The University of Sydney, 380 Werombi Road, Camden, NSW 2570, Australia
}

(Submitted 10 October 2015 - Final revision received 14 February 2016 - Accepted 14 March 2016 - First published online 3 May 2016)

\section{Abstract}

High-producing dairy cows enter a period of negative energy balance during the first weeks of lactation. Energy intake is usually sufficient to cover the increase in energy requirements for fetal growth during the period before calving, but meeting the demand for energy is often difficult during the early stages of lactation. A catabolic state predominates during the transition period, leading to the mobilisation of energy reserves (NEFA and amino acids) that are utilised mainly by the liver and muscle. Increased uptake of mobilised NEFA by the liver, combined with the limited capacity of hepatocytes to either oxidise fatty acids for energy or to incorporate esterified fatty acids into VLDL results in fatty liver syndrome and ketosis. This metabolic disturbance can affect the general health, and it causes economic losses. Different nutritional strategies have been used to restrict negative effects associated with the energy challenge in transition cows. The provision of choline in the form of rumen-protected choline (RPC) can potentially improve liver function by increasing VLDL exportation from the liver. RPC increases gene expression of microsomal TAG transfer protein and APOB100 that are required for VLDL synthesis and secretion. Studies with RPC have looked at gene expression, metabolic hormones, metabolite profiles, milk production and postpartum reproduction. A reduction in liver fat and enhanced milk production has been observed with RPC supplementation. However, the effects of RPC on health and reproduction are equivocal, which could reflect the lack of sufficient dose-response studies.

\section{Key words: Transition dairy cows: Rumen-protected choline: Liver: Fatty liver syndrome}

The term 'transition dairy cow' was introduced in the 1990s and refers to the period from approximately 3 weeks before calving to 3 weeks after calving ${ }^{(1,2)}$. This is a period of profound change in the metabolic and endocrine status of cows to prepare them first for parturition and then for lactation ${ }^{(1)}$. The increase in demand for energy and protein for accelerated fetal growth can often be met despite the 30-35\% decline in DM intake (DMI) that typically occurs during the final week before calving ${ }^{(3)}$. However, a combination of hormonal changes and reduction in appetite during the period of increased energy demand for milk production results in a negative energy balance (NEB) in the period immediately after calving. This leads to lipolysis and the mobilisation of adipose tissue reserves ${ }^{(4,5)}$. There is a 5- to 10-fold increase in circulating concentrations of NEFA and the accumulation of TAG in the liver ${ }^{(6-8)}$. Although the oxidative capacity of the liver increases by $20 \%$ during the final 3 weeks before calving ${ }^{(9)}$, the influx of NEFA into the liver overwhelms hepatic oxidation and the capacity of the liver to secrete esterified fatty acids (FA) (or TAG) as VLDL. The result is that
TAG accumulates and the cow is likely to experience 'fatty liver' (FL) syndrome ${ }^{(6,10)}$. The latter precipitates hepatic dysfunction. The failure of the liver to use the excessive amounts of NEFA as fuel leads to a ketotic state that is associated with increased production and secretion of ketone bodies, primarily $\beta$-hydroxybutyrate $(\beta$-HB) and acetoacetate, and to a lesser extent acetone ${ }^{(10,11)}$. About $50-60 \%$ of transition dairy cows experience moderate to severe FL and ketosis, and this remains a major challenge for production and the health and welfare of dairy cows ${ }^{(12,13)}$

An increase in plasma NEFA contributes to oxidative stress and non-specific and uncontrolled inflammatory responses in transition dairy cows. Elevated NEFA is known to be a common link between metabolic disease (FL, ketosis) and infectious disease (mastitis, Salmonellosis, metritis) around the time of calving $^{(11,14)}$. A compromised immune system is often a feature of the transition dairy cow ${ }^{(15,16)}$. Of particular importance is the negative impact of inflammatory responses on the antimicrobial activity of macrophages and neutrophils. When the functions of

Abbreviations: BCS, body condition score; DMI, DM intake; ER, endoplasmic reticulum; FL, fatty liver; GH, growth hormone; IGF-I, insulin-like growth factor-I; MTTP, microsomal TAG transfer protein; NEB, negative energy balance; PC, phosphatidylcholine; RPC, rumen-protected choline.

* Corresponding author: R. A. Jassim, email r.aljassim@uq.edu.au 
these leucocytes are compromised, pathogens are able to establish long-term disease ${ }^{(14)}$. It was suggested that strategies that reduce lipid mobilisation may also reduce the influence of inflammatory responses on animal general performance in the weeks around calving ${ }^{(14)}$.

Transition cows need to be well managed to avoid inflammatory infection and metabolic disease, trauma, digestive disorders, heat and oxidative stress, and dystocia ${ }^{(17)}$. Subclinical inflammation can have a detrimental effect on metabolic function, as reflected by the development of ketosis and $\mathrm{FL}^{(18,19)}$. Acute-phase proteins (APP), which provide a measure of inflammation, are mainly synthesised in the liver in the days around calving. Pro-inflammatory cytokines produced at the same time by immune cells can disrupt the hepatic synthesis of negative APP such as APOB100, a key component of $\mathrm{VLDL}^{(20,21)}$. Supplementary feeding of rumen-protected choline (RPC) was shown to reduce the negative effects of hepatic lipidosis in transition cows by increasing the expression of FA transport protein 5 and carnitine transporter SLC22A5 in the liver and promote apo B-containing lipoprotein assembly ${ }^{(22)}$. The inclusion of choline in the transition diet can therefore be partially effective in attenuating the negative effects of inflammatory-like condition on hepatic function in transition cows.

The transition dairy cow has understandably been the focus of considerable research, and general reviews are available ${ }^{(14,23,24)}$. The present article provides an overview of the functional and morphological changes in the liver of transition dairy cows, the response of transition dairy cows to the provision of choline and the ability of choline to alleviate FL and some of its consequences.

\section{Metabolic function of the liver in transition dairy cows}

As noted, the energy requirement in dairy cows increases at calving because of the initiation of lactation. Circulating concentrations of NEFA increase immediately after calving because of adipose tissue mobilisation to support lactation ${ }^{(25,26)}$. Hepatic capacity to esterify imported NEFA to TAG increases at the time of parturition $^{(27,28)}$, and the concentrations of TAG in hepatic tissue are elevated by $1 \mathrm{~d}$ postpartum ${ }^{(29-32)}$. Because the uptake of NEFA overwhelms the capacity for hepatic oxidation and secretion of TAG as VLDL (Fig. 1), FL syndrome is common in transition cows ${ }^{(6)}$. Wensing et al. ${ }^{(33)}$ categorised FL by the percentage of TAG in the wet weight of the liver. Normally, TAG comprises $<1 \%$ of the wet weight of the liver, but it can increase to $1-5,5-10$ or $>10 \%$ in mild, moderate and severe FL, respectively ${ }^{(6)}$. Excessive hepatic FA uptake and FL is often accompanied by partial FA oxidation with a consequent increase in production and release of ketone bodies into the general circulation $^{(9,10,12)}$. Ruminants have an inherently low hepatic capacity to synthesise VLDL, and this could be partially attributed to the limited availability of dietary choline for incorporation into phosphatidylcholine for VLDL synthesis in the liver ${ }^{(31)}$.

\section{Molecular and morphological changes of the liver during fatty liver syndrome}

The gross morphological and cellular features of the liver are altered in cows affected by FL. The liver becomes enlarged and swollen as a result of the accumulation of cytosolic lipid droplets in the parenchyma. The colour of the liver changes from dark red to pale yellow ${ }^{(6,34,35)}$. The hepatocytes show a number of morphological changes that include the following: (1) enlargement; (2) mitochondrial damage; (3) compression and decreased volume of nuclei, which results in DNA migration from the core to the anode; (4) decreased volume of rough endoplasmic reticulum (ER); and (5) decreased number of organelles ${ }^{(36-38)}$.

The prolonged exposure $(36-51 \mathrm{~h})$ of hepatocytes to NEFA in vitro reduced ureagenesis and gluconeogenesis ${ }^{(39)}$. Exposure of hepatic tissue to metabolic and inflammatory challenges such as high amounts of NEFA, lipopolysaccharides of microbial origin and TNF- $\alpha$ as one of the pro-inflammatory cytokines during the period of NEB can activate pathways contributing to hepatocyte apoptosis and ER stress ${ }^{(40,41)}$. Biochemical adaptation and symptoms caused by ER stress are similar to those associated with fatty liver, ketosis or inflammation ${ }^{(41)}$. It was reported that thirteen out of fourteen genes of the ER stressinduced unfolded protein response in liver were up-regulated after parturition, and some remained up-regulated even at 14 weeks postpartum - when the cows were already in a positive energy balance ${ }^{(41)}$. This suggested that the high metabolic demand during lactation could induce a certain

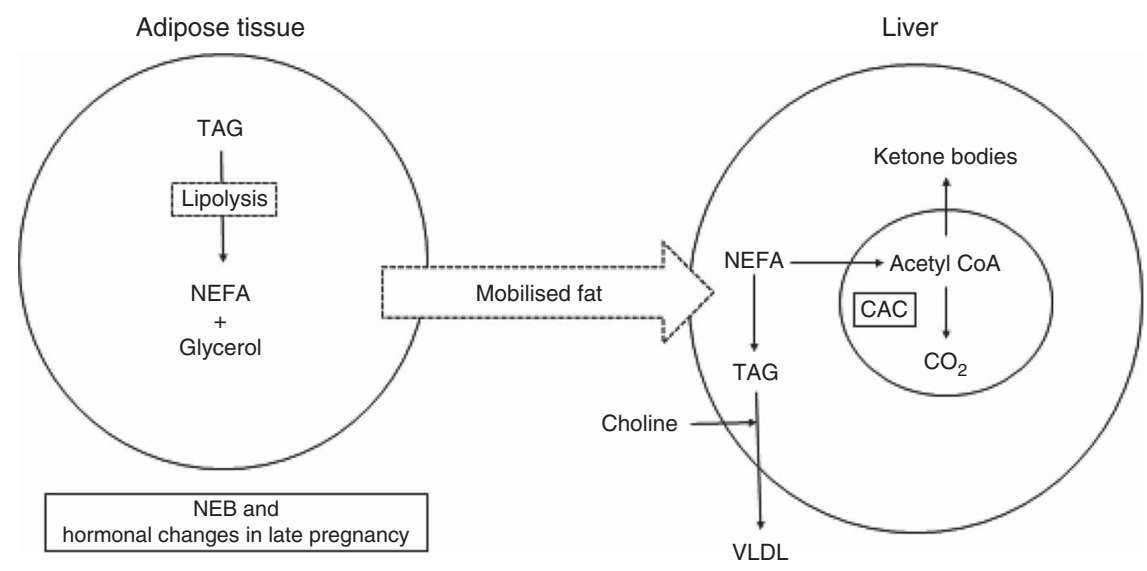

Fig. 1. Role of choline in the export of hepatic NEFA as TAG in form of VLDL. NEB, negative energy balance; CAC, citric acid cycle. 
degree of ER stress without the burden of high NEFA concentration or inflammation ${ }^{(41)}$.

Changes in hepatocyte integrity and function leads to cell necrosis and cell leakage ${ }^{(6)}$. Because of cellular damage, circulating concentrations of hepatic enzymes such as aspartate aminotransferase, $\gamma$-glutamyl transpeptidase, creatine kinase and lactate dehydrogenase are elevated in cows with FL, particularly in severe cases ${ }^{(6)}$. Plasma concentrations of bile constituents (bilirubin, cholic acid and bile acids) increase, demonstrating that bile flow decreases in $\mathrm{FL}^{(6)}$.

Alterations in immune function have been reflected by changes in the expression of hepatic serum amyloid A1 (SAA1), which is involved in neutrophil/macrophage chemotaxis. Expression of mRNA encoding pro-inflammatory cytokines and APP (TNF- $\alpha$, SAA1) is positively correlated with lipid mobilisation from adipose tissue ${ }^{(30)}$. A similar tendency was observed in the expression of other hepatic genes affecting immune function $(I L 27 R A, T H F, I F N G R 2)^{(30,42)}$. Inflammation also contributes to bovine FL and promotes liver TAG accumulation ${ }^{(24)}$. It was suggested that inflammatory pathways may be responsible for decreased glucose production in cows with $\mathrm{FL}^{(24)}$.

The expression of a network of genes that are involved in lipid, carbohydrate and $\mathrm{N}$ metabolism in hepatic tissue is variously altered in cows during peripartum ${ }^{(43)}$. The expression of genes contributing to FA transport (cluster of differentiation 36 (CD36) and acyl-CoA synthetase 1 (ACSL1)) increases in the first $10 \mathrm{~d}$ after calving ${ }^{(42,44,45)}$. Similarly, the expression of genes involved in the esterification of hepatic FA (glycerol-3-phosphate acyl transferase, mitochondrial $(G P A M)$, diacylglycerol $O$-acyltransferase, homology 1 (DGAT1) and glycerol-phosphate acyltransferase 1 (AGPAT 1)) is elevated in the first $10 \mathrm{~d}$ of lactation, contributing to FL development ${ }^{(30,42)}$. The expression of microsomal TAG transfer protein (MTTP), a factor promoting VLDL assembly in the ER, reaches the highest level in hepatic tissue around parturition $^{(22,46,47)}$. Expression of the APOB100 gene is down-regulated in dairy cows approaching parturition, which results in reduced synthesis of hepatic APOB100 ${ }^{(48)}$. In a recent study, no change was found in APOB100 in control cows, but the level was increased at week 6 of lactation in cows that received choline supplementation $^{(22)}$. Cultured dairy cow hepatocytes showed decreased expression of MTTP, APOB100 and APOE when incubated with $\mathrm{NEFA}^{(49)}$. The latter suggested a direct role of mobilised FA in liver gene expression and the aetiology of FL.

\section{Provision of choline in transition dairy cows}

Choline is an important constituent of the cell membrane, found mostly in the form of the phospholipids phosphatidylcholine (PC) and lysophosphatidylcholine, which play a vital role in cellular structure and activity ${ }^{(50-52)}$. Choline is also required for the synthesis of the neurotransmitter acetylcholine, involved in the metabolism of FA in the liver and serves as a methyl donor. It is often incorrectly classified as a member of the vitamin B-complex. It does not qualify as a vitamin because (1) choline is required in greater amounts ( $\mathrm{g} v \mathrm{mg}$ ), (2) it does not serve as a cofactor in enzymatic reactions and (3) it can be synthesised endogenously $^{(50,51)}$. The bioavailability of choline from the diet is very low in ruminants $(<30 \%)$ because of extensive degradation by rumen micro-organisms ${ }^{(53)}$. However, choline can be synthesised in the liver from methionine; therefore, the level of methionine in the metabolic pool is an important factor in determining choline bioavailability in different metabolic pathways. Choline is a direct precursor to betaine in methyl metabolism ${ }^{(52)}$. As a methyl donor, choline is involved in transmethylation reactions that involve folic acid and vitamin $\mathrm{B}_{12}$ such as methionine and carnitine synthesis ${ }^{(50,54)}$ and DNA methylation. PC synthesis is affected by methyl donors' bioavailability, choline and methionine, in the metabolic pool. It has been suggested that PC has more contribution in VLDL synthesis in cows receiving rumenprotected methionine ${ }^{(55)}$. Thus, it is critical to ensure that sufficient amount of methionine is included in the diet. In addition, choline contributes to the cholinergic nervous system by contribution in acetylcholine synthesis. Henning et al. ${ }^{(56)}$ revealed that feeding choline- and methionine-deficient diets leads to reduction of vitamins concentrations including ascorbic acid, $\alpha$ and $\gamma$-tocopherol and retinol, which could lead to epithelial infection, muscle degeneration, liver damage and reduced resistance to infection. The most biologically active form of vitamin $\mathrm{E}, \alpha$-tocopherol, requires hepatic VLDL to be transported via circulation for tissue utilisation, erythrocytes, adipose tissue, heart and skeletal muscles. Hence, choline has an indirect influence on general health, particularly immunity, in humans and animals ${ }^{(56,57)}$.

Hormonal changes at calving and NEB during early lactation are associated with increased hepatic uptake of NEFA and a higher requirement of the liver to metabolise $\mathrm{FA}^{(51)}$. In nonruminants, the availability of $\mathrm{PC}$ is a major factor affecting the rate of VLDL export and susceptibility of the liver to accumulate $\mathrm{TAG}^{(58)}$. This is probably also true in ruminants and low bioavailability of dietary choline, and the greater requirement for VLDL export (Fig. 1) because of increased FA uptake makes the transition dairy cow particularly susceptible to FL.

Inclusion of RPC in the diet of feed-restricted dry cows or transition cows appears to facilitate TAG secretion from the liver ${ }^{(4,22,59,60)}$. This suggests that choline should be considered as an important nutrient in transition dairy cows. However, there are insufficient dose-response data to make a clear case for choline requirement in transition dairy cows. Notwithstanding, the ability to reduce liver TAG has been commonly reported when supplementing with $15 \mathrm{~g}$ of RPC/ $\mathrm{d}^{(59,61-63)}$. The effects of supplementary RPC on biochemical, reproductive and productive features of dairy cows are summarised in Tables 1, 2 and 3.

\section{Choline and blood metabolites}

The response of blood metabolites in transition cows to RPC supplementation has been inconsistent. This could be because of (1) the period at which supplementation was started, (2) the duration of supplementation, (3) the level of supplementation or (4) the efficiency of protecting choline from rumen degradation. In some studies, RPC reduced blood NEFA ${ }^{(4,64,65)}$, whereas no effect was observed in other studies ${ }^{(4,62,63,66,67)}$ ' A reduction in plasma NEFA appears not to be because of reduced lipolysis, but rather attributed to a combination of (1) improved buffering and transport of intracellular NEFA, 
Table 1. The effect of rumen-protected choline (RPC) supplementation of dairy cows on NEFA and $\beta$-hydroxybutyrate $(\beta-H B)$

\begin{tabular}{|c|c|c|c|c|c|}
\hline \multirow[b]{2}{*}{ Metabolite* } & \multicolumn{2}{|c|}{ Level of RPC } & \multirow{2}{*}{$\begin{array}{l}\text { Duration } \\
\text { (days relative to calving) }\end{array}$} & \multirow[b]{2}{*}{ Observations/effect } & \multirow[b]{2}{*}{ References } \\
\hline & $g / d$ & $g / d^{*}$ & & & \\
\hline \multirow[t]{10}{*}{ NEFA } & $20 \cdot 0$ & $5 \cdot 0^{*}$ & -14 to +30 & $\downarrow$ & Pinotti et al. ${ }^{(64)}$ \\
\hline & $15 \cdot 0$ & $4.0^{*}$ & -35 to -25 & $\downarrow$ & Cooke et al. ${ }^{(4)}$ \\
\hline & $45 \cdot 0$ & $11.0^{*}$ & -21 to +63 & - & Piepenbrink \& Overton ${ }^{(62)}$ \\
\hline & $60 \cdot 0$ & $15 \cdot 0^{*}$ & & & \\
\hline & $75 \cdot 0$ & $19 \cdot 0^{*}$ & & & \\
\hline & $120 \cdot 0$ & $30.0^{*}$ & 0 to +42 & - & Shahsavari ${ }^{(63)}$ \\
\hline & $60 \cdot 0$ & $15 \cdot 0^{*}$ & -21 to +21 & - & Furken \& Hoedemaker ${ }^{(67)}$ \\
\hline & 90.0 & $22.0^{*}$ & +35 to +63 & _- & Rahmani et al. ${ }^{(111)}$ \\
\hline & 50 & $9 \cdot 4^{*}$ & -21 to +45 & - & Leiva et al. ${ }^{(66)}$ \\
\hline & 100 & $18 \cdot 8^{*}$ & & & \\
\hline \multirow[t]{13}{*}{$\beta-\mathrm{HB}$} & $240 \cdot 0$ & $60.0^{*}$ & 0 to +42 & $\downarrow$ & Shahsavari( ${ }^{(63)}$ \\
\hline & $100 \cdot 0$ & $25 \cdot 0^{*}$ & -21 to 0 & $\downarrow$ & Elek et al. ${ }^{(68)}$ \\
\hline & 200.0 & $50 \cdot 0^{*}$ & 0 to +60 & & \\
\hline & $45 \cdot 0$ & $11.0^{*}$ & -21 to +63 & - & Piepenbrink \& Overton ${ }^{(62)}$ \\
\hline & $60 \cdot 0$ & $15 \cdot 0^{*}$ & & & \\
\hline & $75 \cdot 0$ & $19 \cdot 0^{*}$ & & & \\
\hline & 20.0 & $5 \cdot 0^{*}$ & -14 to +30 & _ & Pinotti et al. ${ }^{(64)}$ \\
\hline & $15 \cdot 0$ & $4.0^{*}$ & -35 to -25 & - & Cooke et al. ${ }^{(4)}$ \\
\hline & $50 \cdot 0$ & $12 \cdot 5^{*}$ & +40 to +50 & - & Chung et $a l^{(69)}$ \\
\hline & $60 \cdot 0$ & $15 \cdot 0^{*}$ & -21 to +42 & _- & Zom et al. ${ }^{(59)}$ \\
\hline & $60 \cdot 0$ & $15 \cdot 0^{*}$ & -21 to +21 & - & Furken \& Hoedemaker ${ }^{(67)}$ \\
\hline & 50 & $9 \cdot 4^{*}$ & -21 to +45 & - & Leiva et al. ${ }^{(66)}$ \\
\hline & 100 & $18 \cdot 8^{*}$ & & & \\
\hline
\end{tabular}

$\uparrow$, Increased; $\downarrow$, decreased; - , no change.

* As choline chloride.

Table 2. The effect of rumen-protected choline supplementation of dairy cows on DM intake (DMI) and milk yield and composition

\begin{tabular}{|c|c|c|c|c|c|}
\hline \multirow[t]{14}{*}{$\mathrm{DMI}$} & 60.0 & $15 \cdot 0^{*}$ & -21 to +42 & $\uparrow$ & Zom et al. ${ }^{(59)}$ \\
\hline & $60 \cdot 0$ & $15 \cdot 0^{*}$ & -28 to +100 & $\uparrow$ & Oelrichs et al. ${ }^{(89)}$ \\
\hline & $30 \cdot 0$ & $7.5^{\star}$ & 0 to +84 & $\uparrow$ & Soltan et al. ${ }^{(90)}$ \\
\hline & $60 \cdot 0$ & $15 \cdot 0^{*}$ & 0 to +70 & $\uparrow$ & Ardalan et al. (61) $^{-1}$ \\
\hline & $60 \cdot 0$ & $15 \cdot 0^{*}$ & -42 to 0 & $\downarrow$ & Ardalan et al. ${ }^{(61)}$ \\
\hline & $45 \cdot 0$ & $11 \cdot 0^{*}$ & -21 to +63 & - & Piepenbrink \& Overton ${ }^{(62)}$ \\
\hline & $60 \cdot 0$ & $15 \cdot 0^{*}$ & & & \\
\hline & $75 \cdot 0$ & $19 \cdot 0^{*}$ & & & \\
\hline & $50 \cdot 0$ & $12.5^{*}$ & +40 to +50 & - & Chung et al. ${ }^{(69)}$ \\
\hline & $90 \cdot 0$ & $22 \cdot 0^{*}$ & +35 to +63 & - & Rahmani et al. ${ }^{(111)}$ \\
\hline & $115 \cdot 0$ & $29 \cdot 0^{*}$ & +80 to +145 & - & Pineda \& Cardoso ${ }^{(95)}$ \\
\hline & 50 & $9 \cdot 4^{*}$ & -21 to +45 & - & Leiva et al. ${ }^{(66)}$ \\
\hline & 100 & $18 \cdot 8^{*}$ & & & \\
\hline & $80 \cdot 0$ & $20 \cdot 0^{*}$ & -14 to +30 & $\begin{array}{c}\text { Yield } \uparrow \\
\text { Protein - } \\
\text { Fat - }\end{array}$ & Pinotti et al. ${ }^{(64)}$ \\
\hline \multirow[t]{11}{*}{ Milk yield and composition } & 60.0 & $15 \cdot 0^{*}$ & 0 to +70 & $\begin{array}{l}\text { Yield } \uparrow \\
\text { Protein } \uparrow\end{array}$ & Ardalan et al. ${ }^{(61)}$ \\
\hline & $56 \cdot 0$ & $14 \cdot 0^{*}$ & 0 to +60 & $\begin{array}{c}\text { Fat } \uparrow \\
\text { Yield } \uparrow \\
\text { Protein - } \\
\text { Fat - }\end{array}$ & Zahra et al. ${ }^{(60)}$ \\
\hline & Meta-analysis & & -21 to +21 & $\begin{array}{c}\text { Yield } \uparrow \\
\text { Protein - } \\
\text { Fat - }\end{array}$ & Grummer ${ }^{(51)}$ \\
\hline & Meta-analysis & & & & \\
\hline & $40 \cdot 0$ & $10 \cdot 0^{*}$ & 0 to +70 & Yield $\uparrow$ & Pinotti et al. ${ }^{(93)}$ \\
\hline & 60.0 & $15 \cdot 0^{*}$ & -21 to +21 & Yield $\downarrow$ & Furken \& Hoedemaker ${ }^{(67)}$ \\
\hline & 90.0 & $22 \cdot 0^{*}$ & +35 to +63 & - & Rahmani et al. ${ }^{(111)}$ \\
\hline & 115.0 & $29.0^{*}$ & +80 to +145 & - & Pineda \& Cardoso ${ }^{(95)}$ \\
\hline & 50 & $9 \cdot 4^{*}$ & -21 to +45 & Yield - & Leiva et al. ${ }^{(66)}$ \\
\hline & 100 & $18 \cdot 8^{*}$ & & $\begin{array}{c}\text { Protein } \uparrow \\
\text { Fat - }\end{array}$ & \\
\hline & & & & Total solids $\uparrow$ & \\
\hline
\end{tabular}

$\uparrow$, Increased; $\downarrow$, decreased; - , no change.

${ }^{*}$ As choline chloride. 
Table 3. The effect of rumen-protected choline supplementation of dairy cows on postpartum disorders, reproductive parameters and gene expression

\begin{tabular}{|c|c|c|c|c|c|}
\hline \multirow[t]{3}{*}{ Postpartum disorders } & $60 \cdot 0$ & $15 \cdot 0^{\star}$ & -25 to +80 & $\begin{array}{l}\text { Reduction of clinical ketosis, mastitis and the number of } \\
\text { cases of mastitis per cow }\end{array}$ & Lima et al..$^{(92)}$ \\
\hline & $60 \cdot 0$ & $15 \cdot 0^{\star}$ & -21 to 0 & $\begin{array}{l}\text { Higher morbidity because of increased incidence of fever } \\
\text { and puerperal metritis, lower incidence of retained fetal membranes }\end{array}$ & Lima et al. ${ }^{(92)}$ \\
\hline & $60 \cdot 0$ & $15 \cdot 0^{*}$ & -21 to +21 & $\begin{array}{l}\text { Lower incidence of subclinical endometritis, higher sickness } \\
\text { rates after day } 100 \text { postpartum, lower numbers of stillbirths }\end{array}$ & $\begin{array}{l}\text { Furken \& } \\
\quad \text { Hoedemaker }^{(99)}\end{array}$ \\
\hline \multirow[t]{4}{*}{ Reproductive parameters } & $240 \cdot 0$ & $60 \cdot 0^{*}$ & 0 to +42 & Increased ovarian follicle growth and earlier resumption of ovulation & Shahsavari ${ }^{63)}$ \\
\hline & $120 \cdot 0$ & $30 \cdot 0^{\star}$ & -21 to +42 & $\begin{array}{l}\text { Increased the proportion of pregnant cows after the first artificial } \\
\text { insemination }\end{array}$ & Shahsavari ${ }^{(63)}$ \\
\hline & $15 \cdot 0$ & $4 \cdot 0^{*}$ & -25 to +80 & $\begin{array}{l}\text { No differences in conception rate, pregnancy loss } \\
\text { and percentage of cows cycling }\end{array}$ & Lima et al. ${ }^{(92)}$ \\
\hline & $60 \cdot 0$ & $15^{\star}$ & -21 to +21 & Higher numbers of cyclic cows in week 5 postpartum & $\begin{array}{l}\text { Furken \& } \\
\quad \text { Hoedemaker }^{(99)}\end{array}$ \\
\hline Gene expression & $60 \cdot 0$ & $14 \cdot 0^{\star}$ & -21 to +42 & $\begin{array}{l}\text { FATP5, SLC22A5 } \uparrow \\
\text { PPAR } a / \delta \uparrow \\
\text { Pyruvate carboxylase } \downarrow \\
\text { MTTP } \uparrow \\
A P O B 100 \uparrow \\
\text { GLUT2 } \uparrow \\
\text { Carnitine palmitoyl transferase } 1 \mathrm{~A}-\end{array}$ & Goselink et al. ${ }^{(22)}$ \\
\hline
\end{tabular}

$\uparrow$, Increased; $\downarrow$, decreased; - , no change.

* As choline chloride.

(2) improved excretion by VLDL transport and (3) improved carbohydrate metabolism ${ }^{(22)}$. Reduced blood concentrations of $\beta$-HB were observed in transition cows supplemented with $\operatorname{RPC}^{(63,65,67,68)}$, but this response was not consistent in all studies ${ }^{(4,59,62,64,66,69)}$. The positive response in some studies could be attributed to the positive contribution of choline in hepatic gene networks to facilitate VLDL synthesis and exportation ${ }^{(22)}$.

\section{Choline and metabolic hormones}

The somatotropic axis comprising growth hormone (GH), the GH receptor and insulin-like growth factor-I (IGF-I) has a central role in regulating nutrient partitioning at different stages of lactation $^{(70)}$. NEB in transition cows disrupts this axis causing a shift from an anabolic state to a catabolic state. It was reported that at the time of parturition GH concentrations are increased, IGF-I concentrations are reduced and GH receptors are decreased by about $50 \%{ }^{(70-72)}$. Metabolic pathways in the liver shift towards gluconeogenesis in preparation for high-glucose demand by the mammary gland ${ }^{(26,73-75)}$. It is likely that $\mathrm{GH}$ exerts a suppressive effect on insulin, leading to reduced synthesis and secretion of insulin by the pancreas ${ }^{(76-80)}$. There is evidence that the effects of insulin in suppressing hepatic gluconeogenesis and promoting the synthesis of IGF-I are attenuated during early lactation ${ }^{(81)}$. Cows maintained under severe NEB had reduced expression of hepatic IGF-I, GH receptors and IGF-binding proteins ${ }^{(82)}$. In a recent in vitro study, higher IGF-I positively affected the expression of hepatic genes involved in hepatic VLDL assembly and secretion in bovine hepatocytes, namely APOB100, MTTP and the LDL receptors $^{(49)}$. The provision of $120 \mathrm{~g}$ of $\mathrm{RPC} / \mathrm{cow}$ per $\mathrm{d}(30 \mathrm{~g}$ choline chloride/cow per $\mathrm{d}$ ) to transition cows from $21 \mathrm{~d}$ before calving to $42 \mathrm{~d}$ after calving did not influence IGF-I concentration ${ }^{(63)}$. A similar finding was observed when multiparous Holstein cows received 50 and $100 \mathrm{~g}$ of RPC/cow per d (9.4 and $18.8 \mathrm{~g}$ of choline chloride/cow per $\mathrm{d}$, respectively) in the last
$21 \mathrm{~d}$ of pregnancy and in the first $45 \mathrm{~d}$ of lactation ${ }^{(66)}$. The latter study reported greater concentrations of insulin and haptoglobin in RPC-supplemented cows. A positive association between haptoglobin and insulin can partially explain the higher insulin concentration found in RPC-supplemented cows ${ }^{(83,84)}$. In contrast, plasma concentration of insulin did not show major differences in multiparous Holstein cows that received $120 \mathrm{~g}$ of RPC ( $30 \mathrm{~g}$ of choline chloride/cow per $\mathrm{d}$ ) during the period between 3 weeks before and 3 weeks after calving ${ }^{(63)}$.

\section{Choline and DM intake}

The decline in DMI during the last 3 weeks of pregnancy can reach $32 \%$, with $89 \%$ of the decline occurring during the final week $^{(3)}$. There is evidence to suggest that a significant proportion of this decline can be avoided by feeding low-energy diets $^{(85)}$. However, such diets can only be fed before lactation because of the lower demands for nutrients, particularly energy. Colostrum production immediately before calving initiates increasing energy demand, which rises more sharply in the weeks after calving following lactation ${ }^{(3,31,86,87)}$. Hormonal changes around calving noted above and NEB trigger lipolysis, leading to increased concentration of NEFA in circulation ${ }^{(88)}$. Compared with the non-lactation period, the concentration of hepatic TAG can be elevated 3-fold by calving and can continue to increase thereafter ${ }^{(86)}$.

Zom et al ${ }^{(59)}$ reported that supplying $60 \mathrm{~g}$ of RPC/cow per $\mathrm{d}$ ( $15 \mathrm{~g}$ of choline chloride) from week 3 before calving to week 6 after calving increased DMI from 14.4 to $16.0 \mathrm{~kg} / \mathrm{d}$ and net energy intake from 98.2 to $109 \cdot 1 \mathrm{MJ} / \mathrm{d}$. This was in agreement with an earlier study in which feeding $60 \mathrm{~g}$ of RPC/cow per $\mathrm{d}$ ( $15 \mathrm{~g}$ of choline chloride) to lactating cows from day 28 prepartum to day 100 in milk increased DMI as a percentage of body weight over the entire study period ${ }^{(89)}$. In another study, DMI was increased by $8.4 \%$ in cows supplemented with $30 \mathrm{~g}$ of $\mathrm{RPC} / \mathrm{cow}$ per $\mathrm{d}(7.5 \mathrm{~g}$ of choline chloride) in the first 12 weeks 
of lactation ${ }^{(90)}$. Ardalan et al. $^{(61)}$ reported that feeding $60 \mathrm{~g}$ of $\mathrm{RPC} / \mathrm{cow}$ per $\mathrm{d}$ ( $15 \mathrm{~g}$ choline chloride) from the time of calving until week 10 of lactation increased DMI $(22 \cdot 1 v .18 .9 \mathrm{~kg} / \mathrm{d})$, whereas feeding the same amount of choline before parturition was not associated with increased intake. An interaction between body condition score (BCS) and DMI was reported by Zahra et al. ${ }^{(60)}$. Cows with BCS of $\geq 4$ (scale 1 to 5 ) at 3 weeks before calving ate $1.1 \mathrm{~kg}$ of $\mathrm{DM} / \mathrm{d}$ more from week 3 before calving to week 4 after calving when supplemented with RPC. Cows with lower BCS did not show the same response. Other studies did not demonstrate an effect of RPC on postpartum $\mathrm{DMI}^{(60,62,66,69)}$. A meta-analysis of thirteen studies showed that feeding RPC does not affect feed intake before calving but increases DMI by $0.8 \mathrm{~kg} / \mathrm{d}$ in early lactation ${ }^{(51)}$. Feeding RPC did not affect changes in body condition in transition cows, but this may have been because of increases in milk yield that accompanied increased feed intake $e^{(59,91)}$. It can be concluded that choline can indirectly affect DMI in transition cows by restricting the detrimental effects of fatty liver syndrome (FLS) and ketosis on general health ${ }^{(65)}$. Positive responses can be associated with fewer incidences of postpartum disorders such as mastitis and retained fetal membrane (RFM) in transition cows $^{(65,92)}$

\section{Choline and milk yield}

Pinotti et al. ${ }^{(64)}$ reported that RPC supplementation of Italian Holstein multiparous cows during the period from $14 \mathrm{~d}$ before calving to $30 \mathrm{~d}$ after calving at a rate of $20 \mathrm{~g}$ of choline chloride/ cow per $\mathrm{d}$ increased milk yield without affecting the concentrations of fat or protein. Supplementing dairy cows fed alfalfa hay- and maize silage-based total mixed ration (TMR) with $60 \mathrm{~g}$ of RPC/d (providing $15 \mathrm{~g}$ choline chloride) during the first 10 weeks of lactation increased the $40 \mathrm{~g} / \mathrm{kg}$ fat-corrected milk ( $4 \% \mathrm{FCM}$ ) yield by $3.28 \mathrm{~kg} / \mathrm{d}$ and the yield of both fat and protein $^{(61)}$. Multiparous Holstein cows that received 50 and $100 \mathrm{~g}$ of RPC/cow per d (9.4 and 18.8 g of choline chloride/cow per $\mathrm{d}$ ) for $21 \mathrm{~d}$ before calving and $45 \mathrm{~d}$ after calving, respectively, had higher milk protein, total solids and fat concentration $^{(66)}$. In contrast, no treatment effect was observed on fatcorrected milk or on solid-corrected milk yield ${ }^{(66)}$. Primiparous and multiparous Holsteins fed a maize silage-, haylage- and grass hay-based TMR produced more milk $(1.2 \mathrm{~kg} / \mathrm{d})$ during the first $60 \mathrm{~d}$ of lactation when supplemented with $56 \mathrm{~g}$ of RPC/d ( $14 \mathrm{~g}$ of choline chloride) ${ }^{(60)}$. Cows with BCS $\geq 4$ (scale $1-5$ ) showed greater increases in milk yield than cows with lower $\mathrm{BCS}^{(60)}$. The analysis of data from 11 studies revealed a positive milk yield response when RPC was supplemented at $>40 \mathrm{~g}$ of RPC/d (>10 g of choline chloride) ${ }^{(93)}$. A meta-analysis of thirteen trials indicated that RPC supplementation during the transition period increased milk yield by an average of $3.9 \mathrm{~kg} / \mathrm{d}^{(51)}$; however, milk protein and fat percentage were not affected. Another meta-analysis that included studies beyond the transition period found that milk fat content was not influenced by $\mathrm{RPC}^{(94)}$. It was suggested that the increase in protein yield is possibly because of the provision of methyl groups and methionine sparing ${ }^{(94)}$. A recent study showed that inclusion of
RPC in the diet of mid-late lactation dairy cows can alter the milk fat profile by increasing the proportion of $n-3$ content ${ }^{(95)}$; however, milk yield, $3.5 \%$ fat-corrected milk and energycorrected milk were not affected. On the basis of the above overview, it can be speculated that dietary choline can directly and indirectly promote milk production in dairy cows. The direct effect may reflect a higher level of available methionine for milk synthesis and lower hepatic TAG, leading to enhanced gluconeogenesis in the liver ${ }^{(22)}$. The indirect effect is based on a positive production response due to general health improvement in transition cows.

\section{Choline and postpartum disorders}

FL and ketosis are common problems in high-yield dairy herds shifting from transition to lactation stage ${ }^{(10,31)}$. Feeding $60 \mathrm{~g}$ of $\mathrm{RPC} / \mathrm{cow}$ per d ( $15 \mathrm{~g}$ of choline chloride) between $25 \mathrm{~d}$ before and $80 \mathrm{~d}$ after calving reduced the incidence of clinical ketosis and morbidity, and also reduced the incidence of mastitis ${ }^{(92)}$. The occurrence of RFM was lower for cows that received $15 \mathrm{~g}$ of choline/d as RPC for the last $21 \mathrm{~d}$ of gestation, but cows fed RPC had an increased incidence of fever and tended to have more puerperal metritis ${ }^{(92)}$. The positive responses could be attributed to fewer incidences of metabolic challenges around calving associated with general health improvement.

\section{Choline and reproductive measures}

As previously discussed, the disruption of metabolic homoeostasis in early lactation is associated with alterations in the profile of metabolic hormones and metabolites ${ }^{(6,31,72)}$. These changes have negative consequences for ovarian follicular function, the resumption of ovulation and fertility in cows $(6,96)$. For example, IGF-I in concert with insulin has a critical role in ovarian responsiveness to follicle-stimulating hormone (FSH) and luteinising hormone (LH). IGF-I can act synergistically with FSH and LH to enhance ovarian development, steroidogenesis and embryonic development ${ }^{(70,97)}$. Reduced plasma concentrations of IGF-I in early lactation can lead to decreased ovarian follicular growth and lower fertility ${ }^{(72,98)}$.

Variable reproductive responses to choline supplementation have been observed in transition cows. Oelrichs et al. ${ }^{(89)}$ reported that conception and pregnancy rates increased by feeding RPC during the transition period, whereas in another study there were no differences in conception rate, pregnancy loss and percentage of cows cycling ${ }^{(92)}$. A recent study showed that feeding $60 \mathrm{~g}$ of $\mathrm{RPC} / \mathrm{cow}$ per $\mathrm{d}$ ( $15 \mathrm{~g}$ of choline chloride) from $21 \mathrm{~d}$ prepartum to $21 \mathrm{~d}$ postpartum was associated with less endometritis, lower number of stillbirths and more cyclic cows in week 5 postpartum ${ }^{(99)}$. Feeding $240 \mathrm{~g}$ of RPC/cow per d (60 g of choline chloride) from parturition to day 42 in milk was associated with increased ovarian follicle growth and earlier resumption of ovulation ${ }^{(63)}$. Feeding $30 \mathrm{~g}$ of choline chloride/ cow per d (120 g of RPC) from day 21 before calving to day 42 after calving increased the proportion of pregnant cows by day 100 postpartum (28v. 40\%) after the first artificial insemination on day 70 after calving ${ }^{(63)}$. In the same study, the level of leptin 
was significantly higher in cows supplemented with RPC. This outcome can probably be attributed to the improvement of the link between metabolic homoeostasis and hypothalamic-pituitaryovarian axis in transition cows. Leptin has an important role in this axis by binding to its specific receptors, kisspeptin, in the hypothalamus and consequently stimulating gonadotropin-releasing hormone release $\mathrm{s}^{(100,101)}$. In addition, leptin receptors have been detected in the ovaries of cattle ${ }^{(102)}$, and leptin has positive effects on oocyte quality and embryo development in cattle ${ }^{(103)}$.

\section{Choline and gene expression}

RPC increased the expression of FA transport protein 5 (FATP5) and carnitine transporter $S L C 22 A 5$ in hepatic tissue ${ }^{(22)}$. These proteins are involved in FA uptake and intercellular transport in the liver ${ }^{(22)}$. The response to RPC might be attributable to the role of choline in carnitine synthesis by the provision of methyl groups $^{(54)}$ or by improving hepatic intake of carnitine ${ }^{(104)}$. Increasing carnitine availability in hepatocytes can reduce TAG accumulation in transition cows by stimulating FA oxidation $^{(105,106)}$. Similar results were obtained when feed intake in mid-lactating cows was restricted to induce a NEB ${ }^{(107)}$. Abomasal infusion of $\mathrm{L}$-carnitine tended to prevent or decrease TAG accumulation but had no apparent effect on the expression of genes involved in gluconeogenesis (pyruvate carboxykinase, pyruvate carboxylase and pyruvate dehydrogenase kinase, isozyme 4, $P D K 4$ ), inflammation (serum amyloid A3; $S A A 3$ ) and signalling (adiponectin receptor 2; ADIPOR2). It was concluded that DMI restriction, but not the infusion of L-carnitine, influenced expression of the above genes ${ }^{(107)}$. It could be suggested that carnitine does not directly affect the expression of genes associated with FA oxidation.

Feeding RPC to transition cows increased expression of the $P P A R \alpha / \delta$ gene, which is involved in regulatory loops of FA oxidation and transport ${ }^{(22,108)}$. Feeding RPC also increased mRNA for GLUT2, a hepatic protein that facilitates glucose release from the liver into blood ${ }^{(109)}$. This would improve carbohydrate metabolism in the liver.

In a nutrition-induced ketosis study, the expression of glucogenic genes pyruvate carboxylase and fructose 1,6-bisphosphatase 1 was up-regulated, whereas phosphoenolpyruvate carboxykinase 1 , which is also an important glucogenic gene, was down-regulated ${ }^{(108)}$. The level of pyruvate carboxylase mRNA was positively correlated with total fat in the liver and plasma concentrations of NEFA and $\beta-\mathrm{HB}^{(110)}$. An increase in the expression of pyruvate carboxylase and PDK4 was also reported in mid-lactating cows subjected to $\mathrm{NEB}^{(107)}$. The increase in the expression of pyruvate carboxylase and PDK4 indicates a hepatic response to increased demand for glucose for the lactating mammary gland during NEB. The increase in expression of the pyruvate carboxylase gene was reduced in cows receiving RPC before and after calving, suggesting that RPC improves energy status and carbohydrate metabolism in the liver and reduces the need for pyruvate carboxylase ${ }^{(22)}$. RPC supplementation during the transition period affected the expression of two key genes involved in VLDL synthesis (MTTP and $A P O B 100)^{(22)}$. MTTP promotes VLDL synthesis in the $\mathrm{ER}^{(46)}$ and reduces the accumulation of TAG in hepatic tissue. As mentioned earlier, $A P O B 100$ is a key protein required for VLDL synthesis ${ }^{(48)}$. RPC had no effect on mRNA abundance for carnitine palmitoyl transferase $1 \mathrm{~A}^{(22)}$. This suggested that the transport of longchain FA into mitochondria is not affected by the provision of choline in transition cows ${ }^{(42,45)}$

\section{Conclusion}

Choline is an important nutrient and vital for the neurotransmitter acetylcholine, cell membrane structure and function, and hepatic VLDL synthesis. Lactating cows experiencing NEB during early lactation develop moderate to severe FLS because of an inability of the liver to cope with a high influx of NEFA. Under these conditions, supplementary choline can complement dietary choline to meet the increasing demand for the synthesis of PC, involved in the export of TAG from the liver. Given the extensive ruminal degradation of natural dietary choline, and the tremendous influx of FA into the liver during the transition period, it is reasonable to assume that choline is deficient in transition dairy cows. In support of this assumption, supplementation with RPC reduces TAG accumulation in the liver in transition dairy cows. The benefits of RPC supplementation in transition cows have been observed at the animal level (increased milk yield), organ level (reduce hepatic TAG) and cellular level (increased expression of MTTP and ApoB100 mRNA). Further research is required to determine optimal dietary levels of RPC for transition dairy cows and to elucidate the mechanism(s) of action of choline more precisely.

\section{Acknowledgements}

The authors gratefully acknowledge support from the Nancy Roma Paech Bequest to Professor Michael J. D'Occhio for the endowed chair at The Sydney of University. Arash Shahsavari received postgraduate financial support from The University of Queensland (position number 3022886).

All authors contributed to the literature search, manuscript writing and revisions of the article.

The authors declare that there are no conflicts of interest.

\section{References}

1. Grummer RR (1995) Impact of changes in organic nutrient metabolism on feeding the transition dairy cow. J Anim Sci 73, 2820-2833.

2. Drackley JK (1999) Biology of dairy cows during the transition period: the final frontier? J Dairy Sci 82, 2259-2273.

3. Hayirli A, Grummer RR, Nordheim EV, et al. (2002) Animal and dietaryfactors affecting feed intake during the prefresh transition period in holsteins. J Dairy Sci 85, 3430-3443.

4. Cooke R, Del Rio NS, Caraviello D, et al. (2007) Supplemental choline for prevention and alleviation of fatty liver in dairy cattle. J Dairy Sci 90, 2413-2418.

5. Rossi F, Righi F, Romanelli S, et al. (2008) Reproductive efficiency of dairy cows under negative energy balance conditions. Ann Fac Medic Vet Difarma 28, 173-180. 
6. Bobe G, Young JW \& Beitz DC (2004) Invited review: pathology, etiology, prevention, and treatment of fatty liver in dairy cows. J Dairy Sci 87, 3105-3124.

7. Leblanc $S$ (2010) Monitoring metabolic health of dairy cattle in the transition period. J Repr Develo 56, Suppl., S29-S35.

8. Grummer RR (1993) Etiology of lipid-related metabolic disorders in periparturient dairy cows. J Dairy Sci 76, 3882-3896.

9. Drackley JK, Overton TR \& Douglas GN (2001) Adaptations of glucose and long-chain fatty acid metabolism in liver of dairy cows during the periparturient period. J Dairy Sci $\mathbf{8 4}$, E100-E112.

10. Herdt TH (2000) Ruminant adaptation to negative energy balance. Influences on the etiology of ketosis and fatty liver. Vet Clin North Am Food Anim Pract 16, 215-230.

11. Goff J (2006) Major advances in our understanding of nutritional influences on bovine health. J Dairy Sci 89 , 1292-1301.

12. Duffield T (2000) Subclinical ketosis in lactating dairy cattle. Vet Clin North Am Food Anim Pract 16, 231-253.

13. Erb HN \& Grohn YT (1988) Epidemiology of metabolic disorders in the periparturient dairy cow. J Dairy Sci $\mathbf{7 1}$, $2557-2571$.

14. Sordillo LM \& Raphael W (2013) Significance of metabolic stress, lipid mobilization, and inflammation on transition cow disorders. Vet Clin North Am Food Anim Pract 29, 267-278.

15. Suriyasathaporn W, Daemen AJ, Noordhuizen-Stassen EN, et al. (1999) $\beta$-hydroxybutyrate levels in peripheral blood and ketone bodies supplemented in culture media affect the in vitro chemotaxis of bovine leukocytes. Vet Immunol Immunopathol 68, 177-186.

16. Wathes DC, Cheng Z, Chowdhury W, et al. (2009) Negative energy balance alters global gene expression and immune responses in the uterus of postpartum dairy cows. Physiol Genom 39, 1-13.

17. Turk R, Juretić D, Gereš D, et al. (2005) Serum paraoxonase activity in dairy cows during pregnancy. Res Vet Sci 79, 15-18.

18. Bertoni G, Trevisi E, Calamari L, et al. (2006) The inflammation could have a role in the liver lipidosis occurrence in dairy cows. In Production Diseases in Farm Animals, pp. 157-158 [NP Joshi and TH Herdt, editors]. Wageningen: Wageningen Academic Publishers.

19. Ametaj B, Bradford B, Bobe G, et al. (2005) Strong relationships between mediators of the acute phase response and fatty liver in dairy cows. Can J Anim Sci 85, 165-175.

20. Fleck A (1989) Clinical and nutritional aspects of changes in acute-phase proteins during inflammation. Proc Nutr Soc $\mathbf{4 8}$, $347-354$

21. Gruys E, Toussaint M, Landman W, et al. (1998) Infection, inflammation and stress inhibit growth. Mechanisms and non-specific assessment of the processes by acute phase proteins. Production diseases in farm animals, 10th International Conference, Utrecht, the Netherlands, 1998.

22. Goselink R, van Baal J, Widjaja H, et al. (2012) Effect of rumen-protected choline supplementation on liver and adipose gene expression during the transition period in dairy cattle. J Dairy Sci 96, 1102-1116.

23. Chagas LM, Bass JJ, Blache D, et al. (2007) Invited review: new perspectives on the roles of nutrition and metabolic priorities in the subfertility of high-producing dairy cows. J Dairy Sci 90, 4022-4032.

24. Bradford B (2011) Connecting transition cow physiology, behaviour, and nutrition. In Proceedings of the 10th Western Dairy Management Conference. Reno, NV, 9-11 March, pp. 207-220.
25. Emery RS, Liesman JS \& Herdt TH (1992) Metabolism of long chain fatty acids by ruminant liver. J Nutr 122, Suppl., 832-837.

26. Reynolds CK, Aikman PC, Lupoli B, et al. (2003) Splanchnic metabolism of dairy cows during the transition from late gestation through early lactation. J Dairy Sci $\mathbf{8 6}$, 1201-1217.

27. Grum DE, Drackley JK, Younker RS, et al. (1996) Nutrition during the dry period and hepatic lipid metabolism of periparturient dairy cows. J Dairy Sci 79, 1850-1864.

28. Litherland NB, Dann HM \& Drackley JK (2011) Prepartum nutrient intake alters palmitate metabolism by liver slices from peripartal dairy cows. J Dairy Sci 94, 1928-1940.

29. Adewuyi A, Gruys E \& Van Eerdenburg F (2005) Non esterified fatty acids (NEFA) in dairy cattle. A review. Vet $Q$ 27, 117-126.

30. Drackley JK, Dann HM, Douglas GN, et al. (2005) Physiological and pathological adaptations in dairy cows that may increase susceptibility to periparturient diseases and disorders. Ital J Anim Sci 4, 323-344.

31. Grummer RR (2008) Nutritional and management strategies for the prevention of fatty liver in dairy cattle. Vet $J \mathbf{1 7 6}$, $10-20$.

32. Skaar TC, Grummer RR, Dentine MR, et al. (1989) Seasonal effects of prepartum and postpartum fat and niacin feeding on lactation performance and lipid metabolism. J Dairy Sci 72, 2028-2038.

33. Wensing T, Kruip T, Geelen MJH, et al. (1997) Postpartum fatty liver in high-producing dairy cows in practice and in animal studies. The connection with health, production and reproduction problems. Comp Haematol Int 7, 167-171.

34. Tharwat M, Oikawa S, Buczinski S, et al. (2012) Ultrasonographic prediction of hepatic fat content in dairy cows during the transition period. J Vet Sci Technol 3, 5.

35. Morrow D, Hillman D, Dade A, et al. (1979) Clinical investigation of a dairy herd with the fat cow syndrome. J Am Vet Med Assoc 174, 161-167.

36. Tharwat M, Endoh D \& Oikawa S (2012) Hepatocyte apoptosis in dairy cows with fatty infiltration of the liver. Res Vet Sci 93, 1281-1286.

37. Johannsen U, Menger S, Staufenbiel R, et al. (1993) Investigations on morphology and function of the liver of high-yielding cows 2 weeks postpartum. Dtsch Tierarztl Wochenschr 100, 177-181.

38. Reid I \& Collins R (1980) The pathology of post-parturient fatty liver in high-yielding dairy cows. Invest Cell Pathol $\mathbf{3}$, 237-249.

39. Strang BD, Bertics SJ, Grummer RR, et al. (1998) Effect of long-chain fatty acids on triglyceride accumulation, gluconeogenesis, and ureagenesis in bovine hepatocytes. J Dairy Sci 81, 728-739.

40. Ringseis R, Gessner DK \& Eder K (2015) Molecular insights into the mechanisms of liver-associated diseases in early-lactating dairy cows: hypothetical role of endoplasmic reticulum stress. J Anim Physiol Anim Nutr (Berl) 99, 626-645.

41. Gessner DK, Schlegel G, Ringseis R, et al. (2014) Up-regulation of endoplasmic reticulum stress induced genes of the unfolded protein response in the liver of periparturient dairy cows. BMC Vet Res 10, 46.

42. Loor JJ, Dann HM, Everts RE, et al. (2005) Temporal gene expression profiling of liver from periparturient dairy cows reveals complex adaptive mechanisms in hepatic function. Physiol Genomics 23, 217-226.

43. Loor J (2010) Genomics of metabolic adaptations in the peripartal cow. Animal 4, 1110-1139. 
44. Bionaz M \& Loor JJ (2008) ACSL1, AGPAT6, FABP3, LPIN1, and SLC27A6 are the most abundant isoforms in bovine mammary tissue and their expression is affected by stage of lactation. J Nutr 138, 1019-1024.

45. Van Dorland H, Richter S, Morel I, et al. (2009) Variation in hepatic regulation of metabolism during the dry period and in early lactation in dairy cows. J Dairy Sci 92, 1924-1940.

46. Wetterau JR, Lin M \& Jamil H (1997) Microsomal triglyceride transfer protein. Biochim Biophys Acta Lipids Lipid Metab 1345, 136-150.

47. Loor JJ, Dann HM, Guretzky NAJ, et al. (2006) Plane of nutrition prepartum alters hepatic gene expression and function in dairy cows as assessed by longitudinal transcript and metabolic profiling. Physiol Genomics 27, 29-41.

48. Bernabucci U, Ronchi B, Basiricò L, et al. (2004) Abundance of mRNA of apolipoprotein $\mathrm{B}_{100}$, apolipoprotein $\mathrm{E}$, and microsomal triglyceride transfer protein in liver from periparturient dairy cows. J Dairy Sci $\mathbf{8 7}$, 2881-2888.

49. Li X, Guan Y, Li Y, et al. (2015) Effects of insulin-like growth factor- 1 on the assembly and secretion of very low-density lipoproteins in cow hepatocytes in vitro. Gen Comp Endocrinol 226, 82-87.

50. Lima F, Filho MF S, Greco L, et al. (2007) Effects of feeding rumen-protected choline (RPC) on lactation and metabolism. J Dairy Sci 90, Suppl. 1, 174 Abstr.

51. Grummer R (2012) Choline: a limiting nutrient for transition dairy cows. In Proceedings of the Cornell Nutrition Conference, pp. 21-28 [R Grummer, editor]. Syracuse, NY: Cornell University.

52. Santos JEP \& Lima FS (2007) Feeding rumen-protected choline to transition dairy cows. In Proceedings of the 20th Annual Florida Ruminant Nutrition Symposium, 10-11 February 2009, Gainesville, FL, pp. 149-159.

53. Sharma B \& Erdman R (1988) Effects of high amounts of dietary choline supplementation on duodenal choline flow and production responses of dairy cows. J Dairy Sci 71, 2670-2676.

54. Bremer J (1983) Carnitine - metabolism and functions. Physiol Rev 63, 1420-1480.

55. Osorio J, Ji P, Drackley J, et al. (2013) Supplemental Smartamine $\mathrm{M}$ or MetaSmart during the transition period benefits postpartal cow performance and blood neutrophil function. J Dairy Sci 96, 6248-6263.

56. Henning SM, Swendseid ME, Ivandic BT, et al. (1997) Vitamins C, E and A and heme oxygenase in rats fed methyl/ folate-deficient diets. Free Radic Biol Med 23, 936-942.

57. Dutta-Roy AK, Gordon MJ, Campbell FM, et al. (1994) Vitamin E requirements, transport, and metabolism: role of $\alpha$-tocopherol-binding proteins. J Nutr Biochem 5, 562-570.

58. Cole LK, Vance JE \& Vance DE (2012) Phosphatidylcholine biosynthesis and lipoprotein metabolism. Biochim Biophys Acta 1821, 754-761

59. Zom R, Van Baal J, Goselink R, et al. (2011) Effect of rumenprotected choline on performance, blood metabolites, and hepatic triacylglycerols of periparturient dairy cattle. J Dairy Sci 94, 4016-4027.

60. Zahra L, Duffield T, Leslie K, et al. (2006) Effects of rumenprotected choline and monensin on milk production and metabolism of periparturient dairy cows. J Dairy Sci 89 , 4808-4818.

61. Ardalan M, Dehghan-Banadaky M, Rezayazdi K, et al. (2011) The effect of rumen-protected methionine and choline on plasma metabolites of Holstein dairy cows. J Agric Sci 149, 639-646.

62. Piepenbrink M \& Overton T (2003) Liver metabolism and production of cows fed increasing amounts of rumenprotected choline during the periparturient period. J Dairy Sci 86, 1722-1733.
63. Shahsavari A (2012) The metabolic and reproductive responses of lactating dairy cows to supplementation with choline. MPhil thesis, The University of Queensland, Gatton, Australia.

64. Pinotti L, Baldi A, Politis I, et al. (2003) Rumen-protected choline administration to transition cows: effects on milk production and vitamin E status. I Vet Med A Physiol Pathol Clin Med 50, 18-21.

65. Esposito G, Irons PC, Webb EC, et al. (2014) Interactions between negative energy balance, metabolic diseases, uterine health and immune response in transition dairy cows. Anim Reprod Sci 144, 60-71.

66. Leiva T, Cooke R, Brandão A, et al. (2015) Effects of rumenprotected choline supplementation on metabolic and performance responses of transition dairy cows. J Anim Sci 93, 1896-1904.

67. Furken C \& Hoedemaker M (2014) Influence of feeding rumen-protected choline to transition dairy cows. Tierärztl Prax Großtiere 42, 11-21.

68. Elek P, Gaál T \& Husvéth F (2013) Influence of rumenprotected choline on liver composition and blood variables indicating energy balance in periparturient dairy cows. Acta Vet Hung 61, 59-70.

69. Chung Y-H, Brown N, Martinez C, et al. (2009) Effects of rumen-protected choline and dry propylene glycol on feed intake and blood parameters for Holstein dairy cows in early lactation. J Dairy Sci 92, 2729-2736.

70. Radcliff RP, McCormack BL, Crooker BA, et al. (2003) Plasma hormones and expression of growth hormone receptor and insulin-like growth factor-I mRNA in hepatic tissue of periparturient dairy cows. J Dairy Sci 86, 3920-3926.

71. Garnsworthy PC, Lock A, Mann GE, et al. (2008) Nutrition, metabolism, and fertility in dairy cows: 1 . Dietary energy source and ovarian function. J Dairy Sci 91, 3814-3823.

72. Lucy M (editor) (2009) Nutrition and reproduction in dairy cattle: how hormones that control milk production affect fertility. Dairy Health and Nutrition Conference.

73. Lomander H (2012) Energy status related to production and reproduction in dairy cows. Swedish University of Agricultural Sciences. PhD thesis, Skara.

74. Knapp JR, Freetly HC, Reis BL, et al. (1992) Effects of somatotropin and substrates on patterns of liver metabolism in lactating dairy cattle. J Dairy Sci 75, 1025-1035.

75. Akers RM (2006) Major advances associated with hormone and growth factor regulation of mammary growth and lactation in dairy cows. J Dairy Sci 89, 1222-1234.

76. Ponsart C, Freret S, Seegers H, et al. (2008) Epidemiological approach of nutritional factors influencing dairy cow fertility during the dry and post partum periods. In Proceedings of the 25th World Buiatrics Congress Factors Affecting Reproductive Performance in the Cow, pp. 76-87 [O Szenci and AC Bajcsy, editors]. Budapest, Hungary: Hungarian Association for Buiatrics.

77. Roche J, Mackey D \& Diskin M (2000) Reproductive management of postpartum cows. Anim Reprod Sci 60, 703-712.

78. Wathes DC, Cheng Z, Fenwick MA, et al. (2011) Influence of energy balance on the somatotrophic axis and matrix metalloproteinase expression in the endometrium of the postpartum dairy cow. Reproduction 141, 269-281.

79. Garnsworthy P, Sinclair K \& Webb R (2008) Integration of physiological mechanisms that influence fertility in dairy cows. Animal 2, 1144-1152.

80. Humblot P, Grimard B, Freret S, et al. (2009) Impact of energy balance on metabolic changes and reproductive 
tissue: consequences for ovarian activity and fertility in dairy and beef cattle. In Recent Advances in Animal Nutrition 2008, pp. 1-14 [PC Garnsworthy and J Wiseman, editors]. Nottingham: Nottingham University Press.

81. Boisclair Y, Wesolowski S, Kim J, et al. (2006) Roles of growth hormone and leptin in the periparturient dairy cow. In Ruminant Physiology: Digestion, Metabolism and Impact of Nutrition on Gene Expression, Immunology and Stress, pp. 327-346 [K Sejrsen, T Hvelplund and MO Nielsen, editors]. Wageningen, the Netherlands: Wageningen Academic Publishers.

82. Fenwick MA, Fitzpatrick R, Kenny DA, et al. (2008) Interrelationships between negative energy balance (NEB) and IGF regulation in liver of lactating dairy cows. Domest Anim Endocrinol 34, 31-44.

83. Steiger M, Senn M, Altreuther G, et al. (1999) Effect of a prolonged low-dose lipopolysaccharide infusion on feed intake and metabolism in heifers. J Anim Sci 77, 2523-2532.

84. Andersson AK, Flodström M \& Sandler S (2001) Cytokineinduced inhibition of insulin release from mouse pancreatic $\beta$-cells deficient in inducible nitric oxide synthase. Biochem Biophys Res Commun 281, 396-403.

85. Janovick N \& Drackley J (2010) Prepartum dietary management of energy intake affects postpartum intake and lactation performance by primiparous and multiparous Holstein cows. J Dairy Sci 93, 3086-3102.

86. Goff J \& Horst R (1997) Physiological changes at parturition and their relationship to metabolic disorders. J Dairy Sci $\mathbf{8 0}$, 1260-1268.

87. Bell AW (1995) Regulation of organic nutrient metabolism during transition from late pregnancy to early lactation. J Anim Sci 73, 2804-2819.

88. Vazquez-Anon M, Bertics S, Luck M, et al. (1994) Peripartum liver triglyceride and plasma metabolites in dairy cows. J Dairy Sci 77, 1521-1528.

89. Oelrichs W, Lucy M, Kerley M, et al. (2004) Feeding soybeans and rumen-protected choline to dairy cows during the periparturient period and early lactation. 2. Effects on reproduction. J Dairy Sci 87, Suppl. 1, 344-349.

90. Soltan M, Mujalliz A, Mandour M, et al. (2012) Effect of dietary rumen protected methionine and/or choline supplementation on rumen fermentation characteristics and productive performance of early lactating cows. Pak J Nutr 11, 221-230.

91. Elek P, Newbold J, Gaal T, et al. (2008) Effects of rumenprotected choline supplementation on milk production and choline supply of periparturient dairy cows. Animal 2, $1595-1601$.

92. Lima F, Sa Filho M, Greco L, et al. (2012) Effects of feeding rumen-protected choline on incidence of diseases and reproduction of dairy cows. Vet J 193, 140-145.

93. Pinotti L, Polidori C, Campagnoli A, et al. (2010) A meta-analysis of the effects of rumen protected choline supplementation on milk production in dairy cows. In Energy and Protein Metabolism and Nutrition, pp. 321-322 [G. Matteo Grovetto, editor]. Wageningen, the Netherlands: Wageningen Academic Publishers.

94. Sales J, Homolka P \& Koukolová V (2010) Effect of dietary rumen-protected choline on milk production of dairy cows: a meta-analysis. J Dairy Sci 93, 3746-3754.
95. Pineda A \& Cardoso F (2015) Effects of rumen-protected choline with calcium salts of long chain fatty acids on milk yield and milk composition of middle and late lactation Holstein cows. Livest Sci 175, 47-58.

96. Włodarek J, Jaśkowski J, Nowak W, et al. (2011) Development of ovarian follicles, quality of oocytes and fertility of cows in view of a negative energy balance in the transition period. Med Weter 67, 219-223.

97. Lucy M (2000) Regulation of ovarian follicular growth by somatotropin and insulin-like growth factors in cattle. J Dairy Sci 83, 1635-1647.

98. Zulu VC, Nakao T \& Sawamukai Y (2002) Insulin-like growth factor-I as a possible hormonal mediator of nutritional regulation of reproduction in cattle. J Vet Med Sci 64, 657-665.

99. Furken C \& Hoedemaker M (2014) Einfluss einer Fütterung von pansengeschütztem Cholin in der Transitphase bei Milchkühen. Teil 2: Tiergesundheit und Reproduktionsleistung (Influence of feeding rumen-protected choline to transition dairy cows. Part 1: Health and reproduction). Tierärztl Prax Großtiere 42, 79-87.

100. Delavaud C, Ferlay A, Faulconnier Y, et al. (2002) Plasma leptin concentration in adult cattle: effects of breed, adiposity, feeding level, and meal intake. J Anim Sci 80, 1317-1328.

101. Brann DW, Wade MF, Dhandapani KM, et al. (2002) Leptin and reproduction. Steroids $\mathbf{6 7}, 95-104$.

102. Spicer LJ (2001) Leptin: a possible metabolic signal affecting reproduction. Domest Anim Endocrinol 21, 251-270.

103. Clempson A, Pollott G, Brickell J, et al. (2011) Evidence that leptin genotype is associated with fertility, growth, and milk production in Holstein cows. J Dairy Sci 94, 3618-3628.

104. Carter AL \& Frenkel R (1978) The relationship of choline and carnitine in the choline deficient rat. J Nutr 108, 1748.

105. Schlegel G, Keller J, Hirche F, et al. (2012) Expression of genes involved in hepatic carnitine synthesis and uptake in dairy cows in the transition period and at different stages of lactation. BMC Vet Res $\mathbf{8}, 12$.

106. Carlson D, McFadden J, D'Angelo A, et al. (2007) Dietary L-carnitine affects periparturient nutrient metabolism and lactation in multiparous cows. J Dairy Sci 90, 3422-3441.

107. Akbar H, Bionaz M, Carlson D, et al. (2013) Feed restriction, but not L-carnitine infusion, alters the liver transcriptome by inhibiting sterol synthesis and mitochondrial oxidative phosphorylation and increasing gluconeogenesis in midlactation dairy cows. J Dairy Sci $\mathbf{9 6}, 2201-2213$.

108. Loor JJ, Everts RE, Bionaz M, et al. (2007) Nutrition-induced ketosis alters metabolic and signaling gene networks in liver of periparturient dairy cows. Physiol Genomics 32, 105-116.

109. Zhao F-Q \& Keating AF (2007) Functional properties and genomics of glucose transporters. Curr Genomics 8, 113.

110. Hammon H, Stürmer G, Schneider F, et al. (2009) Performance and metabolic and endocrine changes with emphasis on glucose metabolism in high-yielding dairy cows with high and low fat content in liver after calving. J Dairy Sci $\mathbf{9 2}$, 1554-1566.

111. Rahmani M, Banadaky MD, Kamalyan RH, et al. (2014) Effects of feeding rumen-protected choline and vitamin $\mathrm{E}$ on serum protein fractions, total thiol molecules and total antioxidant capacity in early lactating dairy cows. Glob J Anim Sci Res 2, 337-344. 